\title{
INTESTINAL MYIASIS
}

Jarbas Faraco Maldonado Loureiro ${ }^{1}$, Paulo Alberto Falco Pires Corrêa ${ }^{1}$, Marcelo Averbach ${ }^{1}$, Giulio F. Rossini ${ }^{1}$, José Luiz Paccos ${ }^{1}$, Rafael Torres Melo Cavalcante ${ }^{2}$, Elias Jirjoss Ilias ${ }^{3}$, LiLlana Bahia SecaF ${ }^{4}$

\section{Case Report}

Male individual, 68 years old, married and living in São Paulo (state of São Paulo, Brazil) was referred to Hospital SírioLibanês for investigation of episodes of melena. A colonoscopy was requested. The colonoscopy was performed with introduction of the colonoscope up to the terminal ileum. This intestinal part showed normal endoscopic appearance. The colonoscopy revealed an ulcerated fungating lesion with an infiltrative appearance in the rectosigmoid transition. Biopsies were performed in this region. The histopathological diagnosis was infiltrative adenocarcinoma. A rectal sessile polyp was found measuring $0.3 \mathrm{~cm}$ and showing regular margins and smooth surface. A polypectomy was carried out. The histopathological diagnosis was tubular adenoma with low-grade dysplasia. In the transverse colon, there was a tiny ring-like parasite that was motionless and was not attached to the colon mucosa. Parasite removal was attempted using a biopsy forceps, but there was fragmentation of the specimen. The photos of the examination were analyzed by a pathologist who concluded that it was a myiasis.

\section{Discussion}

Myiasis is a disease caused by maggots of Cochliomyia hominivorax, Dermatobia hominis, and Cordylobia anthropophagi, commonly known as "screw-worm fly", "human botfly" and "tumbu fly," respectively. Although these species have different geographical distribution and evolutionary cycles, they have similar clinical characteristics. Regarding location, myiases can be cutaneous (skin and subcutaneous tissue) or cavitary. Biologically, they may be classified as accidental (when a person accidentally eats eggs or maggots of flies in food - intestinal or urinary) or mandatory (when the fly requires a live or dead host to lay its eggs or maggots). Maggots develop in fresh wounds, nostrils, gums, vulva, and anus, among other sites. Initially, there is intense itching and then local pain in the myiases affecting cutaneous and mucosal areas and there may occur secondary infection. In cases of accidental myiases (intestinal or urinary), the diagnosis can be established by means of endoscopy and cystoscopy. We could not find reports of colonic myiases in the medical literature at Medline-Pubmed.

The purpose of reporting this case is to present an uncommon endoscopic finding, keeping in mind that its photographic documentation is critical to help establish the final diagnosis.

\section{Colonoscopy}
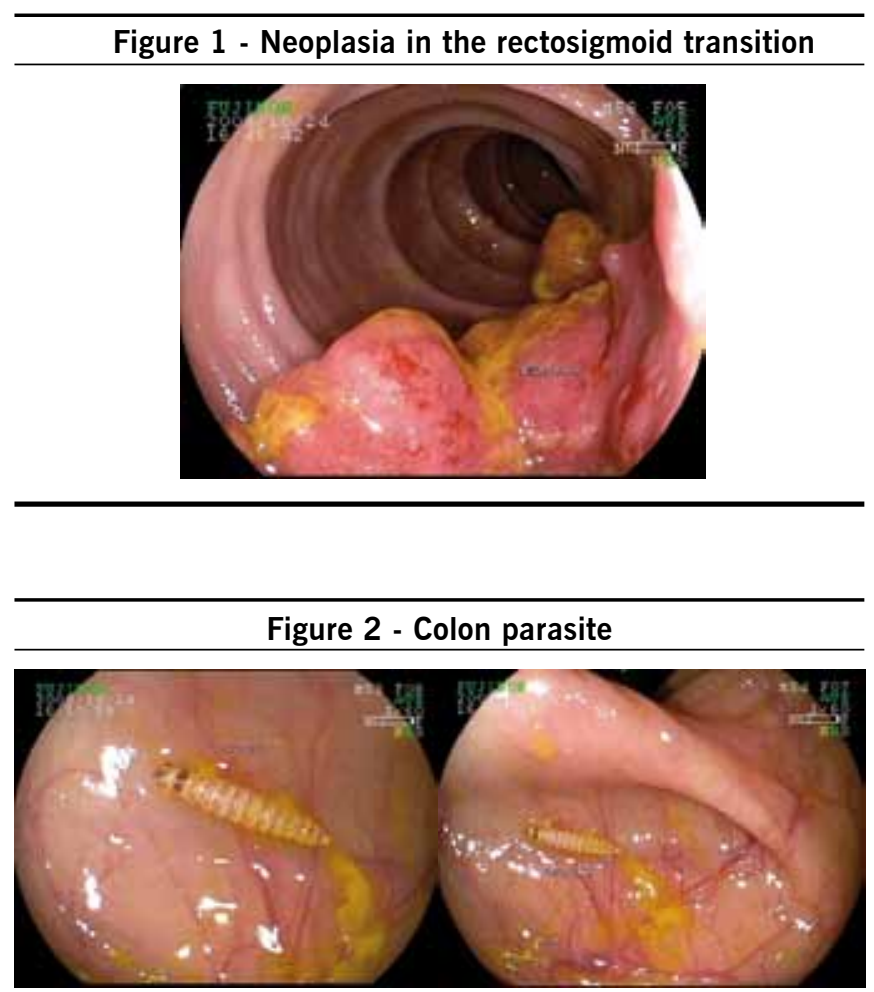

1. Médicos colonoscopistas do Serviço de Endoscopia Digestiva do Hospital Sírio- Libanês, São Paulo, SP

2. Residente do Serviço de Endoscopia Digestiva do Hospital Sírio-Libanês, São Paulo, SP

3. Professor Convidado do Departamento de Cirurgia da Faculdade de Ciências Médicas da Santa Casa de São Paulo, São Paulo, SP

4. Médica Nefrologista do Hospital Sírio-Libanês, São Paulo, SP 